\title{
A NOVEL VALIDATION OF THE LEVOFLOXACIN DETERMINATION METHOD IN URINE (IN VITRO) USING HIGH-PERFORMANCE LIQUID CHROMATOGRAPHY- UV/VIS DETECTOR
}

\author{
I. Sopyan ${ }^{1,3, *}$, D. Dwiputri ${ }^{2}$ and Muchtaridi Muchtaridi ${ }^{2}$ \\ ${ }^{1}$ Departement of Pharmaceutics and Technology Pharmacy, Faculty of Pharmacy, Universitas \\ Padjadjaran, Bandung, 45362, Indonesia. \\ ${ }^{2}$ Departement of Pharmaceutical Analysis and Medicinal Chemistry, Faculty of Pharmacy, \\ Universitas Padjadjaran, Bandung, 45362, Indonesia. \\ ${ }^{3}$ Departement of Drug Discovery and Drugs Development, Faculty of Pharmacy, Universitas \\ Padjadjaran, Bandung, 45362, Indonesia. \\ *E-mail: i.sopyan@unpad.ac.id
}

\begin{abstract}
Levofloxacin (LFX) is a fluoroquinolone antibiotic, which so far, has no method of determining its level in urine using solid-phase extraction (SPE) technique followed by quantification with high-performance liquid chromatography (HPLC) with a UV-Vis detector. The purpose of this study is to find a selective and fast method for examining levofloxacin in the urine. This analysis used a high-performance liquid chromatography method, using a C18 inverse phase column, the stationary phase (column) used was octadecyl silane (ODS) $250 \times 2.6 \mathrm{~mm}, 10 \mu \mathrm{m}$ particle size, using a mixture of phosphate buffer: acetonitrile $(85.5: 14.5, \mathrm{v} / \mathrm{v}) \mathrm{pH} 2.5$ as a mobile phase, with a flow rate of 1.2 $\mathrm{mL} / \mathrm{min}$ and using ciprofloxacin (CFX) as internal standard (IS). Levofloxacin was detected at a wavelength of 295 $\mathrm{nm}$ using a UV detector with a levofloxacin retention time of 9-10 minutes and a resolution of 1.7 from urine. Linearity was obtained by using the internal standard of ciprofloxacin $10 \mu \mathrm{g} / \mathrm{mL}$ with a concentration of levofloxacin $1.15,2.8$, $5,75,11.5$, and $23 \mu \mathrm{g} / \mathrm{mL}$, the correlation coefficient $(\mathrm{r})=0.999$. The limit of detection (LOD) of levofloxacin and limit of quantitation (LOQ) and were $0.0733 \mu \mathrm{g} / \mathrm{mL}$ and 0.0220 , respectively. The percent recovery based on an area of 1.15 and $23 \mu \mathrm{g} / \mathrm{mL}$ was $106.84 \%$ and $89.37 \%$, based on the peak height of $109.52 \mu \mathrm{g} / \mathrm{mL}$ and $91.90 \mu \mathrm{g} / \mathrm{mL}$, relative standard deviation (RSD) precision (\%) respectively $1.09 \%$ and $0.45 \%$ based on area and based on peak heights of $12.66 \%$ and $1.13 \%$. The concentration accuracy value of $1.15,5,75$, and $23 \mu \mathrm{g} / \mathrm{mL}$ were $86.23 \%, 99.98 \%$, and $97.95 \%$ while the precision was $2.78 \%, 5.27 \%$, and $1.14 \%$. The results of the system suitability test and repeatability to retention time, area ratio, and peak height showed coefficient variation RSD $<15 \%$. The results of the validation method meet the requirements so that it can be used to determine levofloxacin in the urine for routine analysis
\end{abstract} Keywords: Validation, Levofloxacin, Urine, HPLC, UV-Vis.

(C) RASĀYAN. All rights reserved

\section{INTRODUCTION}

Levofloxacin (LFX) is a broad-spectrum antibiotic that is effective against many Gram-positive and Gramnegative bacteria, so levofloxacin is often used empirically for widespread infections (pneumonia, urinary tract infections before specific causes are known). ${ }^{1,2}$ Levofloxacin is a relatively new fluoroquinolone antibiotic and it is a drug of choice for infections. However, the method of determining the levels is not widely known, especially in biological fluids such as from blood and urine, so that research is needed to get a simple, fast, accurate, and validated analytical method for pharmacokinetic and pharmacodynamic analysis purposes. ${ }^{3,4}$

Validation of the analytical method is an action taken as proof of certain parameters that are required and determined so that the analysis carried out gets the desired results. This validation is done because of differences in tools, limitations of equipment, chemicals or other conditions that ensure the method cannot 
RASĀYAN J. Chem.

Vol. 13 | No. 4 |2207-2214| October - December | 2020

be applied as a whole, so it is necessary to modify, simplify and improve the method by using solid-phase extraction (SPE) by HPLC with a UV detector. ${ }^{5}$ This analysis method requires several parameters, which include linearity, precision, accuracy, detection limit (LOD), and quantitation limit (LOQ) ${ }^{6,7}$

The development of levofloxacin determination in pharmaceutical preparations has been carried out by conductometry, potentiometry, spectrophotometry, ${ }^{8}$ and by HPLC with UV detectors ${ }^{9}$, while in biological fluids (plasma/urine) HPLC has used fluorescence detectors. ${ }^{3,5,10,11}$ diode array detectors, and spectrometers mass. ${ }^{12}$ Several procedures and techniques have been developed to determine levofloxacin levels in the biological liquid matrix, including the HPLC method ${ }^{1,13,14}$, microdialysis, ${ }^{3}$ fluorimetry, ${ }^{15,16}$ and chemiluminescence, ${ }^{8}$ anodic stripping voltammetry, ${ }^{17}$ potentiometry,${ }^{8}$ flow injection spectrophotometric ${ }^{18}$, and LC-MS. ${ }^{19}$ Based on research that has been carried out, there is no combination of levofloxacin analysis using HPLC-SPE-UV-Vis detector. This research is intended to produce a simple, fast, and accurate method that can be used for levofloxacin analysis in biological fluids, which is for routine analysis purposes.

\section{EXPERIMENTAL}

\section{Materials}

The material used in this analysis was Levofloxacin Comparative Raw (Zhejiang Jinxin-China), ciprofloxacin (Zhejiang, Jinxin, China). Sodium dihydrogen phosphate dihydrate p.a (Merck ${ }^{\circledR}$, Germany), acetonitrile p.a (Merck ${ }^{\circ}$, Germany), and phosphate acid (Merck $\left.{ }^{\circledR}\right)$, methanol pro liquid chromatography (J.T Baker, USA), and aquabidest (IPHA Pharmindo, Indonesia).

\section{Tools}

The equipment used in this analysis is a set of high-performance liquid chromatography tools (Shimadzu LC-10 ATVP, Japan) which consists of an SPD UV-VIS detector, Shimadzu SCL-A System Auto Controler injector, HPLC column (Phenomenex, Germany), $250 \mathrm{~mm}$ long, inner diameter of $2.6 \mathrm{~mm}$, particle size of $10 \mu \mathrm{m}$, a set of UV-Vis spectrophotometer (analytical Jena, specord 200, Germany), pH meter (Ohmeter), Germany, ultrasonic bath (NEY 1510), SPE cartridge HLB 30 mg 1 cc (Oasis, Swiss).

\section{Determination of A UV-Vis Wavelength for Levoflocin \\ Preparation of Mobile Phase}

Sodium dihydrogen phosphate dihydrate weighed $(1.7248 \mathrm{~g}$ ), was dissolved into a $500 \mathrm{~mL}$ volumetric flask, diluted with aquabidest to the limit mark, Then added a drop of phosphate acid was added dropwise to obtain a phosphate buffer with a $\mathrm{pH}$ of 2.5 using a $\mathrm{pH}$ meter. The mobile phase used is the ratio between the phosphate buffer $0.025 \mathrm{M} \mathrm{pH} 2.5$ with acetonitrile (85.5:14.5 v/v).

\section{Preparation of Levofloxacin Calibration Curve}

Standard of a levofloxacin was accurately weighed as much as $50 \mathrm{mg}$, dissolved in a $100 \mathrm{~mL}$ volumetric flask using the mobile phase to the boundary markers so that the final concentration of $0.5 \mathrm{mg} / \mathrm{mL}$ was obtained.

\section{Determination of Maximum Wavelength of Levofloxacin}

The final concentration of the standard solution is $5 \times 10^{-3} \mathrm{mg} / \mathrm{mL}$, then the solution is cleansed with an ultraviolet spectrophotometer at a wavelength of $200-380 \mathrm{~nm}$, to obtain the maximum wavelength of levofloxacin.

\section{Calculation of Molar Extinction ( $(\varepsilon)$}

Levofloxacin standard solution of $0.5 \mathrm{mg} / \mathrm{mL}$ was prepared series of solution $(6.4,10.8$, and $13.5 \mu \mathrm{M})$ using $0.05 \mathrm{M} \mathrm{HCl}$ in a $50 \mathrm{~mL}$ volumetric flask. The three solutions were then analyzed by spectrophotometer, and the absorption at a maximum wavelength of $295 \mathrm{~nm}$ was determined, and the molar extinction values were determined using the following expression:

$\boldsymbol{\varepsilon}=\mathrm{A} / \mathrm{b} \mathrm{C}$

$\mathrm{b}=$ thick of cuvet $(\mathrm{cm}) ; \mathrm{C}=$ consentration (Molar) 
RASĀYAN J. Chem.

Vol. 13 | No. 4 |2207-2214| October - December | 2020

Determination of Optimum HPLC Condition

To obtain the optimum conditions of levofloxacin with SI ciprofloxacin, experiments with various combinations of mobile phases were appropriate (Table-1).

Table 1. Optimation for a HPLC analysis condition.

\begin{tabular}{c|c}
\hline Column & $\begin{array}{c}\text { Octadecyl silane/ } \mathrm{C}_{18} \text { (Phenomenex), length } 250 \mathrm{~mm}, \text { internal diameter dalam } 2.6 \mathrm{~mm}, \\
\text { and particle size } 10 \mu \mathrm{m}\end{array}$ \\
\hline Mobile phase & $\begin{array}{c}\text { Sodium dihydrogen phosphate }(0,025 \mathrm{M}, \mathrm{pH} 2,5): \text { acetonitrile }(85: 15 \mathrm{v} / \mathrm{v}) \\
\text { and }(85,5: 14,5 \mathrm{v} / \mathrm{v})\end{array}$ \\
\hline Flow rate & $1.0 \mathrm{dan} 1.2 \mathrm{~mL} / \mathrm{minute}$ \\
\hline Injection volume & $10 \mu \mathrm{L}$ \\
\hline Internal standard & $10 \mu \mathrm{g} / \mathrm{mL} \mathrm{ciprofloxacin}$ \\
\hline Detection & $\mathrm{UV} 295 \mathrm{~nm}$ \\
\hline
\end{tabular}

\section{Extraction Using SPE (Oasis HLB 1CC)}

SPE cartridge conditioning was conducted using methanol:water $(1: 3 \mathrm{~mL})$, loading sample stage was employed by put on the sample concentration to be measured, then carried out washing stage using $3 \%$ methanol in aquabidest, and the last stage was eluting, using $20 \% \mathrm{ACN}$ in a phosphate buffer $0.025 \mathrm{M}$ at $\mathrm{pH}$ 2.5. The results of elution were collected for HPLC analysis.

\section{Recovery Extraction for SPE}

Recovery extraction was carried out to concentrations 1.15 and $23 \mu \mathrm{g} / \mathrm{mL}$, and it was calculated using equation (1) below:

$\%$ Recovery $=\frac{\text { Peak Area Plasma Chromatogram }}{\text { Peak Area Mobile Phase Chromatogram }} \times 100 \%$

\section{HPLC Validation Method for Determining Level of Levofloxacin Determination of Selectivity}

Selectivity was expressed by the value of resolution or separability (Rs) $\geq 1.5$. It was calculated using equation (2):

$$
\mathrm{Rs}=\left[2\left(\mathrm{t}_{2}-\mathrm{t}_{1}\right) /\left(\mathrm{W}_{1}+\mathrm{W}_{2}\right)\right]
$$

Where, $\mathrm{T}=$ retention time and $\mathrm{W}=$ wide at $10 \%$ of peak).

\section{Repeatability Test}

At the optimum condition, the levofloxacin standard solution concentration of $1.15 \mu \mathrm{g} / \mathrm{mL}$ in urine, as much as $10 \mu \mathrm{l}$ was injected into the HPLC, the experiment was repeated six times then the coefficient of variation was calculated and stated as RSD (\%).

\section{Linearity Studies}

Five series of levofloxacin were made with concentrations $(1.15,2.8,5.75,11.5$, and $23 \mu \mathrm{g} / \mathrm{mL})$ using the internal standard of ciprofloxacin with a concentration of $10 \mu \mathrm{g} / \mathrm{mL}$ in urine, then extracted using SPE with the conditioning step. Linear equations were determined to determine the correlation coefficient ( $\mathrm{r}$ ) between the concentrations of levofloxacin from the ratio of the area of levofloxacin to the internal standard of ciprofloxacin, with a correlation coefficient value $>0.99$.

\section{Determination of LOD and LOQ}

The detection limit and the quantitation limit for levofloxacin content determination can be calculated statistically from a calibration curve equation using a linear regression line.

The limit of detection (LOD) is stated with equation (3):

$$
\mathrm{LOD}=\frac{3 \mathrm{Sb}}{\mathrm{a}}
$$


RASĀYAN $J$. Chem.

Vol. 13 | No. 4 |2207-2214| October - December | 2020

The limit of quantitation (LOQ was calculated using equation (4):

$$
\mathrm{LOQ}=\frac{10 \mathrm{Sb}}{\mathrm{a}}
$$

\section{Test of Accuracy and Precision}

Accuracy and precision on the same day were obtained by determining the levels of three samples $(n=3)$ for three times in a row. The accuracy was obtained by looking at the closeness of the results of the sample to the nominal value and precision seen from the RSD (\%), recovery is calculated by equation (5):

$$
\% \text { Recove ry }=\left[\frac{\mathrm{CT}}{\mathrm{CA}}\right] \times 100 \%
$$

Where, CT is the measured concentration of levofloxacin, and CA is the amount of levofloxacin that is administered (nominal concentration) into the urine. Precision is expressed as RSD (\%), by equation (6):

$$
\% \mathrm{RSD}=\left(\frac{\mathrm{SD}}{\overline{\mathrm{X}}}\right) \mathrm{X} 100 \%
$$

\section{System Suitability Studies}

From the chromatogram obtained, for each concentration determined, repeat the injection of a standard solution expressed in RSD (\%) less than 15\% of the retention time, area ratio, and peak height ratio of the chromatogram. The system suitability test was carried out on levofloxacin samples with a final concentration of 1.15 (low concentration) and $23 \mu \mathrm{g} / \mathrm{mL}$ for (high concentration) in urine, with an internal standard of ciprofloxacin, $10 \mu \mathrm{g} / \mathrm{mL}$, respectively. Each repetition was carried out six times $(n=6)$ with an injection volume of $10 \mu \mathrm{l}$ into the HPLC device at optimum conditions.

\section{Determination of Measurement Wavelength}

\section{RESULTS AND DISCUSSION}

The results of the wavelength of the standard solution of levofloxacin and ciprofloxacin as an internal standard, using a comparison of the mobile phase phosphate: acetonitrile (85.5:14.5) obtained the maximum wavelength of levofloxacin $295 \mathrm{~nm}$ and the maximum wavelength of ciprofloxacin $279 \mathrm{~nm}$. The results of the analysis can be seen in Fig.-1. Ciprofloxacin is used as an internal standard due to it has the same structure with levofloxacine so that it can be seen the method to separate the two compounds.

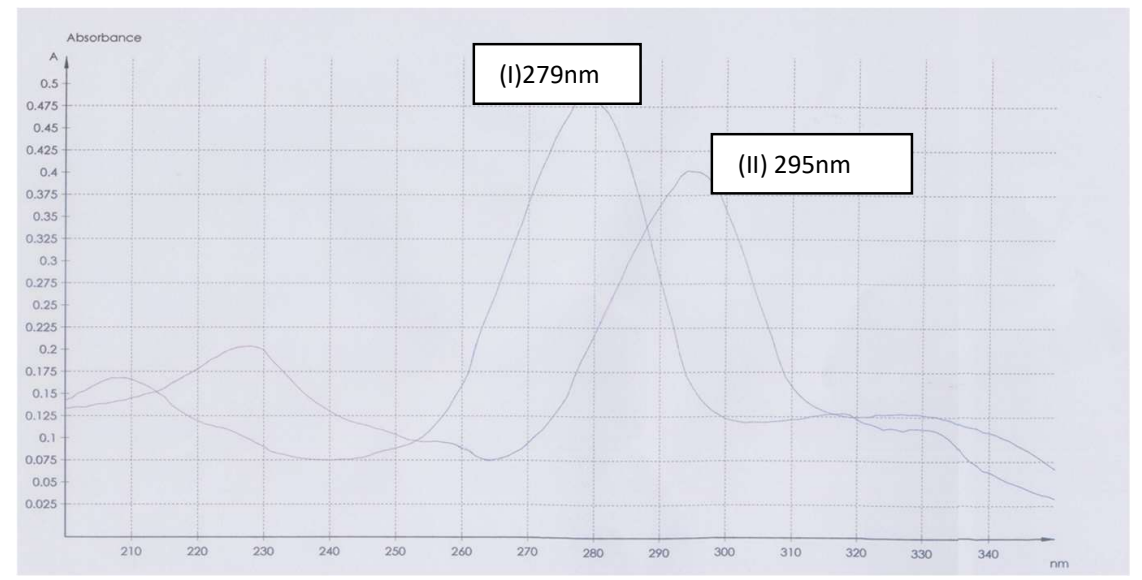

Fig.-1: The Spectrum of Maximum Wavelength

\section{Results of Molar Extinction}

Levofloxacin can be detected using an ultraviolet-visible detector in the HPLC system because the average value of the levofloxacin molar extension $(\varepsilon)$ is $33.002 \mathrm{M}^{-1} \mathrm{~cm}^{-1}$ (see Table-2) greater than the accepted value for molar extinction that is $10.000 \mathrm{M}^{-1} \mathrm{~cm}^{-1} .{ }^{20}$ Its values showed a ability of UvVis detection can be used for levofloxacin and ciprofloxacin.

$$
2210
$$


RASĀYAN J. Chem.

Vol. 13 | No. 4 |2207-2214| October - December | 2020

Table-2: Molar Extinction of Levofloxacin $\mathrm{HCl} 0.1 \mathrm{~N}$ at wavelength $295 \mathrm{~nm}(n=3)$

\begin{tabular}{c|c|c|c}
\hline $\mathrm{n}$ & Concentration $(\mathrm{M})$ & Absorbance & Molar Extinction $(\varepsilon)\left(\mathrm{M}^{-1} \mathrm{~cm}^{-1}\right)$ \\
\hline 1 & 0.0000135 & 0.3896 & 28859.26 \\
2 & 0.0000108 & 0.3624 & 33555.56 \\
3 & 0.00000648 & 0.2343 & 36593.75 \\
\hline$\overline{\mathrm{X}}$ & & & 33002.86 \\
\hline
\end{tabular}

\section{Determination of The Analysis Conditions Result}

The results of determining the optimal conditions based on the conditions that produced resolution values of CFX and LPX peaks (RS) of more than 1.5 and can be seen in Table-3. Selection of the optimal analytical condition is based on the required separation and the fastest retention time of the analyte.

\begin{tabular}{c|l}
\hline \multicolumn{2}{|l}{ Table-3: Optimization Results of HPLC Conditions } \\
\hline Mobile Phase & $\begin{array}{l}\text { Octadecyl silane } / \mathrm{C}_{18} \text { (Phenomenex), length } 250 \mathrm{~mm} \text {, internal diameter } 2.6 \\
\text { mm, and particle size } 10 \mu \mathrm{m}\end{array}$ \\
\hline Flow rate & Sodium dihydrogen phosphate $(0,025 \mathrm{M}, \mathrm{pH} 2,5):$ acetonitrile $(85.5: 14.5 \mathrm{v} / \mathrm{v})$ \\
\hline Volume injection & $10 \mu \mathrm{LL} /$ minute \\
\hline Internal standard & $10 \mu \mathrm{g} / \mathrm{mL}$ ciprofloxacin \\
\hline Detection & $\mathrm{UV} 295 \mathrm{~nm}$ \\
\hline ODS=Octadecylsilane
\end{tabular}

\section{Recovery Extraction Value}

The results of recovery extraction have shown in Table-4. were obtained based on the requirements to enter the range of $80-120 \%$ recovery, and the results of the coefficient of variation (RSD \%) into the range for biological fluids are $<15 \% .{ }^{7,21,22}$ The extraction recovery value shows a good extraction method so that the sample can be drawn completely from the blood plasma.

Table-4: Recovery of Extraction Value $(n=3)$.

\begin{tabular}{|c|c|c|c|c|c|}
\hline & \multicolumn{2}{|c|}{ Peak Area } & & \multicolumn{2}{|c|}{ Height Peak } \\
\hline & \multicolumn{2}{|c|}{$\begin{array}{l}\text { Concentration } \\
(\mu \mathrm{g} / \mathrm{mL})\end{array}$} & & \multicolumn{2}{|c|}{$\begin{array}{l}\text { Concentration } \\
(\mu \mathrm{g} / \mathrm{mL})\end{array}$} \\
\hline & 1.15 & 23 & & 1.15 & 23 \\
\hline & 93.43 & 88.92 & & 93.57 & 90.72 \\
\hline \multirow[t]{2}{*}{$\mathrm{n}=3$} & 111.79 & 89.68 & $\mathrm{n}=3$ & 111.27 & 92.40 \\
\hline & 115.30 & 89.51 & & 118.73 & 92.35 \\
\hline $\bar{X}(\%)$ & 106.84 & 89.37 & $\bar{X}$ & 109.52 & 91.90 \\
\hline RSD \% & 10.9 & 0.45 & $\begin{array}{c}\mathrm{RSD} \\
\%\end{array}$ & 12.66 & 1.13 \\
\hline
\end{tabular}

Notice: RSD= Relative Standard Deviation

\section{Validation Method for Determining Levels of Levofloxacin by HPLC Selectivity}

The results of selectivity can be seen in Fig.-2. The selectivity of a method can be seen from the value of separation between internal standard ciprofloxacin and levofloxacin, as samples showed a good resolution value. It means the method can separate LFX and CPX with a resolution value of $\geq 1.5$. ${ }^{20}$

\section{The Repeatability Test Result}

The repeatability test was carried out using a levofloxacin sample concentration of $1.15 \mu \mathrm{g} / \mathrm{mL}$ with an internal standard concentration of $10 \mu \mathrm{g} / \mathrm{mL}$, repeated with six replications. This test is said to meet the requirements if the value of the area retention time was based on RSD biological fluid $<15 \% .{ }^{20}$ The analysis results obtained by area are $1.3 \%$ while based on $0.66 \%$ retention time so that the repeatability test results are said to meet requirements based on the validation parameters. 
RASĀYAN J. Chem.

Vol. 13 | No. 4 |2207-2214| October - December | 2020

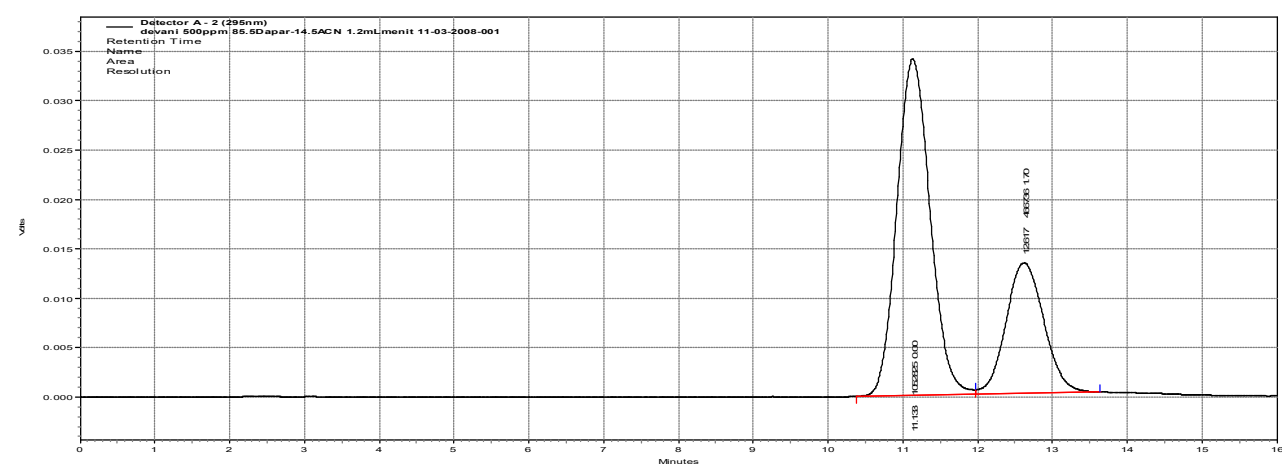

Fig.-2: Chromatogram of Separation of CFX and LFX (Selectivity).

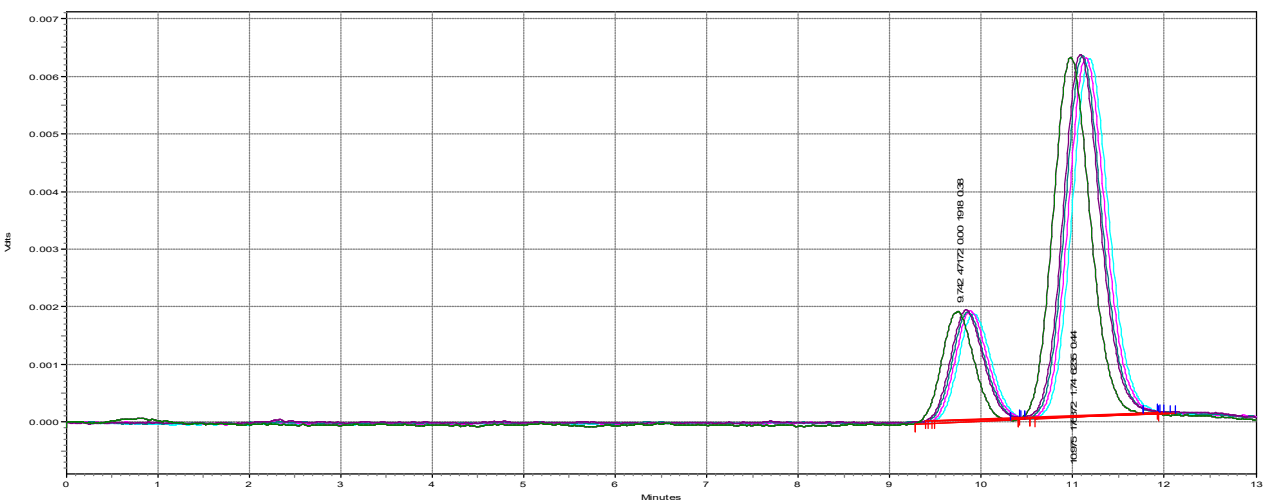

Fig.-3: Chromatogram of Repeatability

\section{Linearity Determination Result}

The linearity test results presented in Fig.-4 and the results of the linear regression equation obtained are $(r)=0.999$, the equation $Y=0.143 x+0.121$. These results meet the linearity test requirements on biological fluids with (r) $>0.995$; the value shows a comparable value between the increase in concentration and the response of the analysis (peak and height area). ${ }^{20,21}$

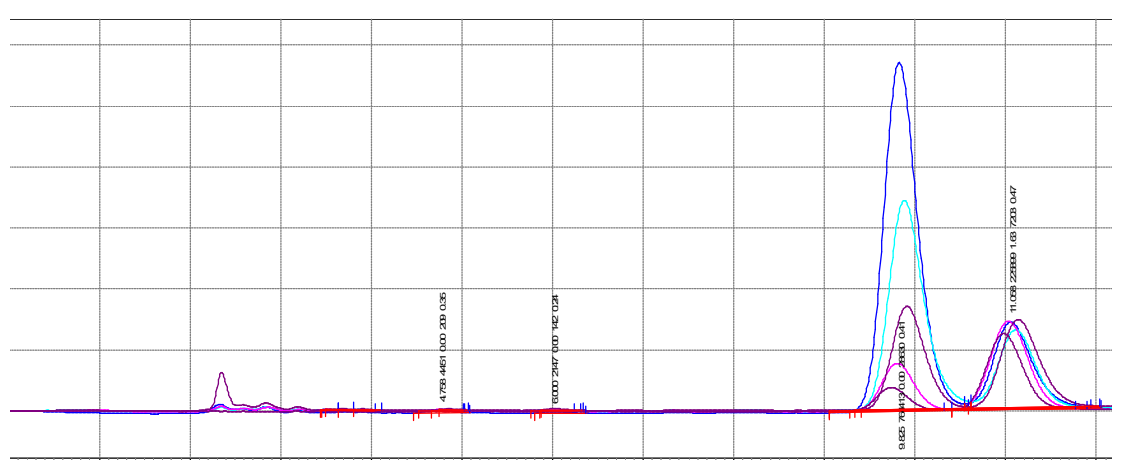

Fig.-4: Chromatogram of Linearity

\section{LOD and LOQ Values Result}

The best correlation coefficient (r) results obtained from the levofloxacin standard curve can be used for testing the limit of detection (LOD). The LOD value of the area ratio is $0.0220 \mu \mathrm{g} / \mathrm{mL}$, and the LOD value based on peak height is $0.1679 \mu \mathrm{g} / \mathrm{mL}$. The LOQ test results were obtained based on the levofloxacin calibration curve of the equation that had the best correlation coefficient of the calibration curve. The LOQ results are obtained from the chromatogram area ratio calibration curve. The LOQ value of the chromatogram area ratio is $0.0733 \mu \mathrm{g} / \mathrm{mL}$, and the LOQ value at peak height was $0.5598 \mu \mathrm{g} / \mathrm{mL}$. Both LOD and LOQ values obtained can be used for both quantitative and qualitative analyses, especially in human urine. Values of LOD and LOQ can be concluded to have the ability to detect an LFX and CFX level in human plasma. 
RASĀYAN J. Chem.

Vol. 13 | No. 4 |2207-2214| October - December | 2020

\section{Accuracy and Precision Value}

Determination of the precision and accuracy, three series of levofloxacin sample concentrations were made in the urine matrix. Low, medium, and high-value calibration curves were taken, respectively $(1.15,5,75$, and $23 \mu \mathrm{g} / \mathrm{mL}$ ), and contained an internal standard of ciprofloxacin $10 \mu \mathrm{g} / \mathrm{mL}$, as shown in Table 4. The value of accuracy from the three concentrations in the range $86 \%-99 \%$ and the precise value at $1 \%-5 \%$, were both accurate and precise and fulfilled the value as required (Table-5). ${ }^{20,22}$

Table-5: \% Accuracy and Precision value $(n=3)$

\begin{tabular}{c|c|c|c|c|c|c|c|c}
\hline \multicolumn{2}{c|}{$\begin{array}{c}\text { Nominal Concentration } \\
(\mu \mathrm{g} / \mathrm{mL})\end{array}$} & \multicolumn{3}{c|}{$\begin{array}{c}\text { Accuracy } \\
\text { (\% Recovery) }\end{array}$} & \multicolumn{3}{c}{$\begin{array}{c}\text { Percision } \\
\text { (\% RSD) }\end{array}$} \\
\hline 1.15 & 5.75 & 23 & 1.15 & 5.75 & 23 & 1.15 & 5.75 & 23 \\
\hline 0.96 & 5.42 & 22.33 & $86.23 \pm 2.40$ & $99.98 \pm 5.27$ & $97.95 \pm 1.12$ & 2.79 & 5.27 & 1.14 \\
0.99 & 5.80 & 22.44 & & & & & & \\
1.02 & 6.02 & 22.82 & & & & & & \\
\hline
\end{tabular}

The Expeiment Conducted $(n=3)$ in intra day $(r=1)$, RSD $=$ Relative Standard Deviation.

\section{Suitability System Test Result}

System suitability test results obtained from the concentration of $1.15 \mu \mathrm{g} / \mathrm{mL}$, meet the requirements of the coefficient of variation $\leq 5 \%,{ }^{20,23}$ as shown in Table- 6 .

\begin{tabular}{c|c|c}
\hline \multirow{2}{*}{ Table-6: Values of Suitability System } \\
\hline \multirow{3}{*}{ Parameter } & RSD $(\%)$ \\
& Concentration of LFX $(1.15 \mu \mathrm{g} / \mathrm{mL})$ \\
\hline \multirow{3}{*}{ Peak area } & LFX & 0.66 \\
& CPX & 0.68 \\
& Ratio & 0.07 \\
\hline \multirow{2}{*}{ Height area } & LFX & 1.30 \\
& CPX & 0.55 \\
& Ratio & 1.33 \\
\hline \multicolumn{2}{|c}{ LFX } & 1.43 \\
& CPX & 0.36 \\
& Ratio & 1.32 \\
\hline \multirow{2}{*}{ CONCLUSION }
\end{tabular}

Based on the results of the research, the following conclusions were obtained. Optimization of HPLC conditions and levofloxacin extraction with urine matrix, using SPE Oasis HLB 1cc, can be done with relatively good results. Based on the results of the validation of the analysis method with parameters of selectivity, accuracy, repeatability, linearity, the limit of detection, the limit of quantitation and suitability of the system, the results obtained showed that the method was carried out according to the required standards so that it can be used to determine levofloxacin using HPLC with a UV detector.

\section{ACKNOWLEDGEMENT}

We would like to thank DRPMI Universitas Padjadajaran for all their support in this research.

\section{REFERENCES}

1. S. Djabarouti, E. Boselli, B. Allaouchiche, B. Ba, A. T. Nguyen, J. B. Gordien, Journal of Chromatography B., 799(1),165(2004), DOI:10.1016/j.jchromb.2003.10.031

2. A. Louie, C. Fregeau, W. Liu, R. Kulawy, G. L. Drusano, Antimicrobial Agents and Chemotherapy. 53(8),3325(2009), DOI:10.1128/AAC.00006-09

3. F.C. Cheng, T.R Tsai, Y. F. Chen, L. C. Hung, T. H. Tsai, Journal of Chromatography A, 961(1),131(2002), DOI:10.1016/S0021-9673(02)00506-X

4. C. H. Nightingale, E. M. Grant, R. Quintiliani, Chemotherapy, 46(Suppl. 1), 6(2000), DOI: $10.1159 / 000048487$ 
RASĀYAN J. Chem.

Vol. 13 | No. 4 |2207-2214| October - December | 2020

5. O. Ballesteros, J. L.Vílchez, A. Navalón, Journal of Pharmaceutical and Biomedical Analysis, 30(4), 1103(2002), DOI:10.1016/S0731-7085(02)00466-1

6. W. Horwitz, AOAC, Guidelines for Single Laboratory, p.38(2012)

7. I. Sopyan, A. Fudhloli, M. Muchtaridi, I. P. Sari, D. Permatasari, International Journal of Research in Pharmaceutical Sciences, 7(4),301(2017).

8. G. Altiokka, Z. Atkosar, N. O. Can, Journal of Pharmaceutical and Biomedical Analysis, 30(3), 881(2002), DOI: 10.1080/10408340701804400

9. P. I. Utami, Thesis, Depertement of ChmIstry, Universitas Gadjah Mada, Yogyakarta (2006)

10. H. A. Nguyen, J. Grellet, B. B. Ba, C. Quentin, M-C. Saux, Journal of Chromatography B, 810(1), 77(2004), DOI:10.1016/j.jchromb.2004.07.019

11. A. Espinosa-Mansilla, A. M. De La Pena, D. G. Gómez, F. Salinas, Journal of Chromatography B. 822(1-2),185(2005), DOI:10.1016/j.jchromb.2005.05.045

12. C. M. Tobin, J. Sunderland, L. O. White, A. P. MacGowan, Journal of Antimicrobial Chemotherapy, 43(3), 434(1999), DOI: 10.1093/jac/43.3.434

13. F. A. Wong, S. J. Juzwin, S. C. Flore, Journal of Pharmaceutical and Biomedical Analysis, 15(6), 765(1997), DOI:10.1016/S0731-7085(96)01890-0

14. M. S. Arayne, N. Sultana, F. A. Siddiqui, Journal of Pharmaceutical Sciences, 20(2),100(2007).

15. O. A. Razak, S. F. Belal, M. M. Bedair, N. S. Barakat, R. S. Haggag, Journal of Pharmaceutical and Biomedical Analysis, 31(4),701(2003), DOI:10.1016/S0731-7085(02)00654-4

16. J. A. O. González, M. C. Mochón, F. J. B de la Rosa, Talanta, 52(6), 1149(2000), DOI:10.1016/S00399140(00)00484-7

17. A. Radi, Z. El-Sherif, Talanta, 58(2), 319(2002), DOI:10.1016/S0039-9140(02)00245-X

18. I. F. Al-Momani, Analytical Letters, 39(4), 741(2006), DOI:10.1080/00032710600611186

19. D. Bao, T. T. Truong, P. J. Renick, M. E. Pulse, W. J. Weiss, Journal of Pharmaceutical and Biomedical Analysis, 46(4), 723(2008), DOI:10.1016/j.jpba.2007.11.023

20. L. R, Snyder, J. J. Kirkland, J.L. Glajch, John Wiley \& Sons (2012), 813 p.

21. Y. Harahap, U. Mansur, T. Sinandang, Pharmaceutical Sciences and Research, 3(1), 22(2012), DOI:10.7454/psr.v3i1.3397

22. M. Muchtaridi, E. Yuliani, I. Sopyan, International Journal of Pharmacy and Pharmaceutical Sciences, 8(1), 255(2015)

23. L. D. Vu1, P. T. Lap, L. V. Tan, Rasayan Jurnal of Chemistry, 11(4), 1537(2018), DOI: $10.31788 /$ RJC.2018.1144061

24. V. Venkateswarlu, K. H. Reddy, Ramireddy, Rasayan Jurnal of Chemistry, 12(3),1584(2019), DOI: 10.31788/RJC.2019.1235210

25. S. Shiyan, T. Hertiani, R. Martien, A. K. Nugroho, Rasayan Jurnal of Chemistry, 12(3),1098(2019), DOI: $10.31788 /$ RJC.2019.1235276

[RJC-6045/2020] 